\title{
Kualitas Hidup Penderita Talasemia berdasarkan Instrumen Pediatric Quality of Life Inventory 4.0 Generic Core Scales di Ruang Rawat Anak Rumah Sakit Umum Cut Meutia Aceh Utara
}

Muhsinun Nikmah, Mauliza

Fakultas Kedokteran Universitas Malikussaleh, Lhokseumawe

Latar belakang. Talasemia merupakan kelainan genetik yang diderita seumur hidup dan akan menimbulkan banyak masalah akibat proses penyakit itu sendiri maupun karena pengobatannya. Hal ini akan memengaruhi kualitas hidup anak.

Tujuan. Mengetahui kualitas hidup penderita talasemia berdasarkan instrumen Pediatric Quality of Life Inventory (PedsQL) 4.0 Generic Core Scales di Ruang Rawat Anak Rumah Sakit Umum Cut Meutia Aceh Utara.

Metode. Penelitian deskriptif dengan desain penelitian cross sectional dengan besar sampel sebanyak 41 orang anak.

Hasil. Hasil analisis univariat didapatkan rerata kualitas hidup subjek penelitian adalah 60,48. Kualitas hidup paling tinggi terdapat pada kelompok usia 13-18 tahun $(68,42)$, jenis kelamin laki-laki $(62,86)$, pendidikan SMA/Sederajat $(81,52)$, kadar Hb pre-transfusi $<9 \mathrm{~g} / \mathrm{dL}(60,51)$, mendapat transfusi 3 bulan terakhir $(61,60)$, lama sakit $>5$ tahun $(65,74)$, dan pendapatan orangtua per bulan $>$ Rp.3.5.000.000 (68,59).

Kesimpulan. Rerata kualitas hidup penderita talasemia di Rumah Sakit Umum Cut Meutia Aceh Utara adalah buruk, khususnya pada fungsi sekolah. Sari Pediatri 2018;20(1):11-6

Kata kunci: talasemia, kualitas hidup, PedsQL

\section{Quality of Life in Patients with Thalassemia by Using Pediatric Quality of Life Inventory 4.0 Generic Core Scales Instrument at Pediatric Ward in Rumah Sakit Umum Cut Meutia Aceh Utara}

Muhsinun Nikmah, Mauliza

Background. Thalassemia is a lifetime genetic disorder which may cause many problems as a result of its disease and its treatment. These will affect quality of life of children with thalassemia.

Objective. To assess quality of life in patients with thalassemia by using Pediatric Quality of Life Inventory (PedsQL) 4.0 Generic Core Scales instrument at pediatric ward in Rumah Sakit Umum Cut Meutia Aceh Utara.

Methods. A descriptive study with cross sectional design. The sample of size is 41 children aged 2-18 years old that calculated with accidental sampling method.

Result. Univariate analysis shows that the mean of total summary score is 60,48 . The most hi highest quality of life is on $13-18$ years old group $(68,42)$, male $(62,86)$, Senior High School degree $(81,52)$, pre-transfusion $\mathrm{Hb}$ level $<9 \mathrm{~g} / \mathrm{dL}(60,51)$, patients with blood transfusion during the previous 3 months $(61,60)$, duration of illness $>5$ years $(65,74)$, and parents' income in a month $>$ Rp.3.500.000 (68,59).

Conclusion. Children with thalassemia in Rumah Sakit Umum Cut Meutia Aceh Utara have low quality of life, especially in school function. Sari Pediatri 2018;20(1):11-6

Keywords: thalassemia, quality of life, PedsQL

Alamat korespondensi: Muhsinun Nikmah. Fakultas Kedokteran Universitas Malikussaleh, Jl. H. Meunasah Uteunkot - Cunda Lhokseumawe 24352. Email: pspd.@gmail.ac.id 
Talasemia merupakan sekelompok penyakit genetik pada produksi rantai globin, yaitu akibat ketidakseimbangan dalam memproduksi rantai globin $\alpha$ dan $\beta .{ }^{1}$ World Health Organization (WHO) pada tahun 2011 melaporkan sekitar 7\% dari populasi dunia membawa gen sifat untuk gangguan $\mathrm{Hb}$, terutama penyakit sel sabit dan talasemia. ${ }^{2}$ Prevalensi talasemia carrier di Indonesia adalah sekitar 3\%-8\%. Jika persentase talasemia mencapai 5\%, dengan angka kelahiran 23 per 1.000 dari 240 juta penduduk, maka diperkirakan ada sekitar 3.000 bayi penderita talasemia yang lahir di Indonesia setiap tahunnya. Aceh merupakan provinsi terbesar yang memiliki penderita talasemia di Indonesia. ${ }^{3}$

Talasemia merupakan salah satu penyakit kronis yang dapat memengaruhi kualitas hidup penderita akibat penyakitnya sendiri maupun efek terapi yang diberikan. ${ }^{4}$ Efek tersebut tidak hanya memengaruhi fungsi fisik anak tetapi juga fungsi sosial, emosional, dan sekolah. ${ }^{5}$

Anak talasemia membutuhkan terapi transfusi darah merah seumur hidup untuk mengatasi kondisi anemia dan mempertahankan kadar Hb. Pemberian transfusi darah berulang dapat menimbulkan komplikasi penimbunan zat besi dalam jaringan tubuh yang dapat menyebabkan kerusakan organ tubuh, seperti hati, ginjal, kelenjar endokrin dan jantung. ${ }^{6}$

Penilaian kualitas hidup terhadap anak talasemia perlu dilakukan untuk menentukan tindakan yang mendukung perbaikan kualitas hidup. ${ }^{7}$ Salah satu instrumen yang direkomendasikan untuk menilai kualitas hidup yaitu Pediatric Quality of Life Inventory (PedsQL). Alasannya adalah karena PedsQL memenuhi persyaratan kelayakan instrumen yang akan digunakan untuk menilai kualitas hidup, seperti memiliki validitas dan reliabilitas yang tinggi dan telah dibuktikan pada beberapa penelitian, tersedia dalam bentuk generik maupun spesifik, bisa diisi oleh anak (self report) ataupun orangtua/wali (proxy report), dan tersedia untuk berbagai kelompok usia, serta kuesioner ini sudah diterjemahkan dalam beberapa versi bahasa yang bertujuan untuk mempermudah pelaksanaannya. ${ }^{8,9,10}$

\section{Metode}

Jenis penelitian ini adalah penelitian deskriptif potong lintang. Penelitian ini dilakukan di Ruang Rawat Anak Rumah Sakit Umum (RSU) Cut Meutia Aceh Utara mulai bulan Februari 2017 sampai Oktober 2017. Populasi dalam penelitian ini adalah jumlah seluruh kunjungan pasien talasemia yang terdata di RSU Cut Meutia Aceh Utara periode September 2016 - Agustus 2017 (411 kunjungan). Besar sampel untuk penelitian deskriptif menurut Gay dan Diehl ${ }^{11}$ adalah minimal $10 \%$ dari populasi. Dengan demikian diperlukan besar sampel minimal 41 orang. Kriteria inklusi adalah pasien ruang rawat anak yang didiagnosis talasemia, berusia 2-18 tahun, serta orangtua dan pasien bersedia mengisi informed consent dan kuesioner yang diberikan. Kriteria eksklusi adalah pasien yang mengalami retardasi mental dan kecacatan fisik, serta pasien yang mengalami penurunan kondisi sehingga tidak memungkinkan untuk ikut serta dalam penelitian ini.

Pengambilan data menggunakan kuesioner PedsQL 4.0 Generic Core Scales dan kuesioner data anak. Kuesioner PedsQL terdiri dari 23 pertanyaan untuk mengukur empat skala multidimensi, yaitu fungsi fisik (8), fungsi emosional (5), fungsi sosial (5), dan fungsi sekolah (5). Setiap skala mendapat penilaian secara terbalik, untuk setiap pemilihan angka nol (tidak pernah, dalam satu bulan terakhir) mendapat nilai 100, satu (hampir tidak pernah, atau satu kali dalam sebulan) mendapat 75, dua (kadangkadang, atau dua kali dalam sebulan) mendapat 50, tiga (sering, atau satu kali dalam seminggu) mendapat 25, dan empat (hampir selalu, atau lebih dari tiga kali dalam seminggu) mendapat nilai nol. Semakin tinggi nilainya semakin baik kualitas hidup responden. Fungsi fisik yang termasuk dalam domain penilaian meliputi kemampuan anak untuk dapat mandiri dalam menjalani aktivitasnya. Fungsi emosional menilai kemampuan anak dalam mengekspresikan rasa marah, sedih, maupun takut. Fungsi sosial menilai kemampuan anak dalam melakukan interaksi dengan teman sebayanya dan kemampuan anak dalam melakukan pergaulan di sekolahnya. Fungsi sekolah adalah kemampuan anak untuk memusatkan perhatian mengerjakan tugas di sekolahnya.

Pencatatan data demografi dan kondisi klinis dilakukan dengan melengkapi kuesioner data anak yang berisi pertanyaan yaitu nama anak, jenis kelamin, tanggal lahir, pendidikan anak, kadar $\mathrm{Hb}$ pre-transfusi, transfusi 3 bulan terakhir, lama sakit, pendidikan ayah, pendidikan ibu, dan rata-rata penghasilan orangtua per bulan.

Penelitian ini telah mendapat persetujuan Komisi Etik tentang penelitian kesehatan dari Lembaga Peneliti Muda Kesehatan Aceh (LPMKA). 


\section{Hasil}

Karakteristik subjek tertera pada Tabel 1 yang menunjukkan bahwa di antara 41 subjek penelitian didapatkan kelompok usia terbanyak adalah 8-12 $(34,15 \%)$ tahun. Subjek penelitian sebagian besar adalah laki-laki 25 (60,98\%). Tingkat pendidikan

Tabel 1. Karakteristik subjek penelitian $(\mathrm{n}=41)$

\begin{tabular}{|c|c|c|}
\hline Karakteristik & Jumlah & $(\%)$ \\
\hline \multicolumn{3}{|l|}{ Usia (tahun) } \\
\hline $2-4$ & 4 & 9,76 \\
\hline $5-7$ & 10 & 24,39 \\
\hline $8-12$ & 14 & 34,15 \\
\hline $13-18$ & 13 & 31,71 \\
\hline \multicolumn{3}{|l|}{ Jenis kelamin } \\
\hline Laki-laki & 25 & 60,98 \\
\hline Perempuan & 16 & 39,02 \\
\hline \multicolumn{3}{|l|}{ Pendidikan } \\
\hline Tidak sekolah & 14 & 34,15 \\
\hline TK & 2 & 4,88 \\
\hline $\mathrm{SD} /$ sederajat & 18 & 43,90 \\
\hline SMP/sederajat & 6 & 14,63 \\
\hline SMA/sederajat & 1 & 2,44 \\
\hline \multicolumn{3}{|l|}{ Pendidikan ayah } \\
\hline Tidak tamat SD & 3 & 7,32 \\
\hline $\mathrm{SD} /$ sederajat & 14 & 34,15 \\
\hline SMP/sederajat & 11 & 26,83 \\
\hline SMA/sederajat & 10 & 24,39 \\
\hline Perguruan tinggi & 3 & 7,32 \\
\hline \multicolumn{3}{|l|}{ Pendidikan ibu } \\
\hline Tidak tamat SD & 4 & 9,76 \\
\hline $\mathrm{SD} /$ sederajat & 9 & 21,95 \\
\hline SMP/sederajat & 12 & 29,27 \\
\hline SMA/sederajat & 12 & 29,27 \\
\hline Perguruan tinggi & 4 & 9,76 \\
\hline \multicolumn{3}{|l|}{ Kadar $\mathrm{Hb}$ pre-transfusi (g/dL) } \\
\hline$<9$ & 40 & 97,56 \\
\hline$>9$ & 1 & 2,44 \\
\hline \multicolumn{3}{|l|}{ Transfusi 3 bulan terakhir } \\
\hline Ya & 36 & 87,80 \\
\hline Tidak & 5 & 12,20 \\
\hline \multicolumn{3}{|l|}{ Lama sakit (tahun) } \\
\hline$<1$ & 4 & 9,76 \\
\hline $1-5$ & 18 & 43,90 \\
\hline$>5$ & 19 & 46,34 \\
\hline \multicolumn{3}{|l|}{ Penghasilan orangtua per bulan } \\
\hline$<$ Rp. 1.500 .000 & 21 & 51,22 \\
\hline Rp. 1.500.000- Rp. 2.500 .000 & 8 & 19,51 \\
\hline Rp. 2.500.000-Rp. 3.500 .000 & 6 & 14,63 \\
\hline$>$ Rp. 3.500.000 & 6 & 14,63 \\
\hline
\end{tabular}

terbanyak adalah SD/sederajat dengan jumlah 18 $(43,90 \%)$ orang. Jumlah tingkat pendidikan terakhir ayah paling banyak adalah SD/sederajat berjumlah 14 $(34,15 \%)$ orang, sedangkan pada tingkat pendidikan ibu terbanyak pada SMP/sederajat dan SMA/sederajat berjumlah masing-masing 12 (29,27\%) orang. Kadar $\mathrm{Hb}$ pre-transfusi didapatkan lebih banyak pada $<9$ $\mathrm{g} / \mathrm{dL}$ dengan jumlah 40 orang dibanding $>9 \mathrm{~g} / \mathrm{dL} 1$ orang. Subjek yang memiliki riwayat transfusi 3 bulan terakhir didapatkan lebih banyak $(87,80 \%)$ dibanding yang tidak memiliki riwayat transfusi 3 bulan terakhir. Subjek penelitian dengan lama sakit terbanyak adalah $>5$ tahun (19 orang). Sebagian besar pendapatan orangtua subjek per bulan adalah $<$ Rp. 1.500.000.

Tabel 2 menunjukkan nilai rerata kualitas hidup 60,48 . Domain kualitas hidup yang paling rendah terdapat pada fungsi sekolah, yaitu dengan nilai rerata 36,96 , sedangkan fungsi sosial memiliki nilai rerata tertinggi 79,02 untuk domain kualitas hidup.

Kelompok usia 13-18 tahun memiliki kualitas hidup paling baik dari segala domain fungsi dengan skor total 68,42 . Fungsi yang paling terganggu pada masing-masing kelompok usia secara keseluruhan adalah fungsi sekolah. Penderita talasemia laki-laki memiliki rerata skor total kualitas hidup lebih tinggi $(62,86)$ dibanding kualitas hidup perempuan $(56,77)$. Rerata skor total kualitas hidup subjek penelitian paling tinggi pada anak dengan pendidikan SMA/sederajat $(81,52)$, dan paling rendah pada kelompok anak tidak sekolah $(54,64)$. Kelompok subjek dengan kadar $\mathrm{Hb}$ pre-transfusi $<9 \mathrm{~g} / \mathrm{dL}$ memiliki rerata skor total kualitas hidup lebih tinggi. Anak yang mendapatkan transfusi darah 3 bulan terakhir memiliki kualitas hidup yang lebih tinggi dibanding anak yang tidak mendapat transfusi darah 3 bulan terakhir. Kualitas hidup subjek penelitian paling tinggi terdapat pada kelompok dengan lama sakit $>5$ tahun, dan juga pada kelompok anak dengan pendapatan orangtua per bulan $>$ Rp. 3.500.000

Tabel 2. Kualitas hidup penderita talasemia

\begin{tabular}{lc}
\hline Domain kualitas hidup & Rerata kualitas hidup \\
\hline Fungsi fisik & 55,67 \\
Fungsi emosional & 69,51 \\
Fungsi sosial & 79,02 \\
Fungsi sekolah & 36,96 \\
Skor fungsi psikososial & 63,44 \\
\hline Skor total & 60,48 \\
\hline
\end{tabular}


Mubsinun Nikmah dkk: Kualitas hidup penderita talasemia berdasarkan instrumen PedsQL 4.0 Generic Core Scales

Tabel 3. Kualitas hidup penderita talasemia berdasarkan karakteristik sosiodemografi dan karakteristik klinis

\begin{tabular}{|c|c|c|c|c|c|c|c|}
\hline Karakteristik & Jumlah & Fungsi fisik & $\begin{array}{c}\text { Fungsi } \\
\text { emosional }\end{array}$ & $\begin{array}{c}\text { Fungsi } \\
\text { sosial }\end{array}$ & $\begin{array}{l}\text { Fungsi } \\
\text { sekolah }\end{array}$ & $\begin{array}{c}\text { Fungsi } \\
\text { psikososial }\end{array}$ & Skor total \\
\hline \multicolumn{8}{|l|}{ Usia (tahun) } \\
\hline $2-4$ & 4 & 24,55 & 32,50 & 57,50 & 7,50 & 43,75 & 35,55 \\
\hline $5-7$ & 10 & 52,19 & 63,50 & 81,50 & 32,33 & 63,97 & 59,47 \\
\hline $8-12$ & 14 & 56,47 & 73,93 & 78,93 & 36,07 & 63,29 & 60,95 \\
\hline $13-18$ & 13 & 67,07 & 80,77 & 83,85 & 39,17 & 68,09 & 68,42 \\
\hline \multicolumn{8}{|l|}{ Jenis kelamin } \\
\hline Laki-laki & 25 & 59,68 & 71,80 & 81,40 & 33,73 & 64,77 & 62,86 \\
\hline Perempuan & 16 & 49,61 & 65,94 & 75,31 & 32,76 & 61,35 & 56,77 \\
\hline \multicolumn{8}{|l|}{ Pendidikan anak } \\
\hline Tidak sekolah & 14 & 52,10 & 61,43 & 75,71 & 27,02 & 61,55 & 57,56 \\
\hline TK & 2 & 64,06 & 67,50 & 92,50 & 36,67 & 67,44 & 66,17 \\
\hline $\mathrm{SD} /$ sederajat & 18 & 54,69 & 74,44 & 77,78 & 36,94 & 63,30 & 60,33 \\
\hline SMP/sederajat & 6 & 58,85 & 70,00 & 83,33 & 34,31 & 64,43 & 62,34 \\
\hline SMA/sederajat & 1 & 87,50 & 95,00 & 95,00 & 45,00 & 78,33 & 81,52 \\
\hline \multicolumn{8}{|l|}{$\mathrm{Hb}$ pre-transfusi $(\mathrm{g} / \mathrm{dL})$} \\
\hline$<9$ & 40 & 55,66 & 70,13 & 78,63 & 33,35 & 63,48 & 60,51 \\
\hline$>9$ & 1 & 56,25 & 45,00 & 95,00 & 33,33 & 61,54 & 59,52 \\
\hline \multicolumn{8}{|l|}{ Transfusi 3 bulan terakhir } \\
\hline Ya & 36 & 58,20 & 68,96 & 79,58 & 33,68 & 63,68 & 61,60 \\
\hline Tidak & 5 & 37,50 & 67,00 & 75,00 & 31,00 & 61,67 & 52,40 \\
\hline \multicolumn{8}{|l|}{ Lama sakit (tahun) } \\
\hline$<1$ & 4 & 36,72 & 55,00 & 70,00 & 42,50 & 56,09 & 49,11 \\
\hline $1-5$ & 18 & 50,60 & 65,56 & 77,50 & 28,70 & 61,88 & 57,45 \\
\hline$>5$ & 19 & 64,47 & 76,32 & 82,37 & 35,83 & 66,46 & 65,74 \\
\hline \multicolumn{8}{|l|}{ Penghasilan orangtua per bulan } \\
\hline$<$ Rp. 1.500 .000 & 21 & 52,83 & 70,95 & 79,52 & 33,77 & 64,62 & 60,05 \\
\hline Rp. 1.500 .000 - Rp. 2.500 .000 & 8 & 49,00 & 51,25 & 71,88 & 25,83 & 52,65 & 51,47 \\
\hline Rp. 2.500.000 - Rp. 3.500 .000 & 6 & 63,54 & 77,50 & 83,33 & 35,00 & 67,64 & 65,88 \\
\hline$>$ Rp.3.500.000 & 6 & 66,67 & 80,83 & 82,50 & 40,28 & 69,47 & 68,59 \\
\hline
\end{tabular}

\section{Pembahasan}

Nilai rerata skor total kualitas hidup penderita talasemia pada penelitian ini sebesar 60,48, hasil tersebut berada di bawah nilai kualitas hidup normal. Varni $\mathrm{dkk}^{12}$ melaporkan kualitas hidup anak dikatakan buruk jika total summary score $<70$. Brown ${ }^{13}$ melaporkan bahwa fungsi psikososial, fungsi fisis, fungsi emosional, fungsi sosial, dan fungsi sekolah ditetapkan sebagai buruk bila $<80$. Hasil penelitian ini lebih rendah dari Raj ${ }^{15} \mathrm{dkk}$ (2017), Agung, ${ }^{16}$ dan Thavorncharoensap ${ }^{9}$ dkk (2010) dengan hasil masing-masing 87,50, 76,67, dan 75,28.

Domain kualitas hidup yang paling rendah adalah fungsi sekolah $(36,96)$. Fungsi sekolah yang buruk diduga akibat frekuensi anak dengan talasemia yang harus meninggalkan sekolah untuk mendapat pengobatan di rumah sakit tinggi akibat tubuh yang kekurangan energi untuk dapat mengikuti aktivitas akademik. ${ }^{9}$ Temuan tersebut sesuai dengan penelitian yang dilakukan oleh Agung. ${ }^{16}$

Fungsi fisik $(55,67)$ adalah fungsi kedua yang terganggu setelah fungsi sekolah. Perubahan fisik subjek yang sangat mencolok disebabkan karena anemia kronis dan pengendapan zat besi pada organ tubuh. Perubahan fisik yang terjadi berupa deformitas tulang wajah, splenomegali, ekspansi sumsum tulang, tubuh pendek, dan berbagai gejala yang diakibatkan oleh hemolisis. Penampilan yang berbeda merupakan faktor penting yang memengaruhi perkembangan kepribadian, seperti citra diri yang kurang, timbul 
rasa malu, penolakan untuk bergaul, dan bersekolah. ${ }^{18}$

Nilai fungsi emosional 69,51 masih dikategorikan buruk. Raj dkk ${ }^{15}$ melaporkan bahwa fungsi emosional merupakan domain kualitas hidup yang paling buruk pada penderita talasemia. Gangguan fungsi emosional dipengaruhi oleh berbagai hal, yaitu perasaan tertekan saat penegakan diagnosis, terapi yang harus dijalani setiap bulan secara teratur, dan keharusan tidak masuk sekolah karena harus menjalani terapi. ${ }^{18}$

Fungsi sosial penelitian ini mencapai nilai tertinggi, yaitu 79,02. Keterbatasan aktivitas fisik membuat subjek tidak dapat melakukan hal-hal yang dapat dilakukan oleh teman sebaya yang sehat. Hasil ini sejalan dengan penelitian sebelumnya yang dilakukan oleh Sultana dkk ${ }^{17}$ di Pakistan.

Kualitas hidup penderita talasemia paling tinggi pada kelompok usia 13-18 tahun. Thavorncharoensap $\mathrm{dkk}^{9}$ menjelaskan bahwa umur responden berpengaruh terhadap kualitas hidup, semakin bertambah usia anak maka kualitas hidupnya bertambah.

Laki-laki memiliki skor total kualitas hidup lebih tinggi $(62,86)$ dibandingkan perempuan $(56,77)$. Hasil penelitian ini sama dengan Raj $\mathrm{dkk}^{15}$ Literatur menjelaskan bahwa jenis kelamin tidak memengaruhi kualitas hidup anak talasemia. Hal tersebut sesuai dengan hukum Mendel bahwa gen talasemia diturunkan secara autosomal resesif tidak tergantung jenis kelamin sehingga anak dari pembawa sifat mempunyai kemungkinan anak lahir normal $25 \%$, sebagai pembawa sifat $50 \%$, dan kemungkinan $25 \%$ adalah penderita. ${ }^{9}$

Kualitas hidup berdasarkan pendidikan subjek penelitian didapatkan lebih tinggi pada tingkat SMA/ sederajat $(81,52)$ dan paling rendah pada subjek yang tidak sekolah $(57,56)$. Hal ini mungkin karena terdapat perbedaan jumlah subjek penelitian yang sangat signifikan pada masing-masing tingkat pendidikan. Menurut Aji dkk, ${ }^{18}$ semakin rendah pendidikan subjek maka fungsi sosialnya semakin buruk.

Rerata skor total kualitas hidup dari 40 subjek penelitian yang memiliki kadar $\mathrm{Hb}$ pre-transfusi $<9$ $\mathrm{g} / \mathrm{dL}$ adalah 60,51 . Nilai ini sedikit lebih tinggi dari subjek dengan kadar $\mathrm{Hb}$ pre-transfusi $>9 \mathrm{~g} / \mathrm{dL}(59,52)$. Hasil ini berbeda dengan penelitian sebelumnya yang melaporkan semakin tinggi kadar $\mathrm{Hb}$ pre-transfusi maka semakin besar nilai kualitas hidup anak. ${ }^{14,9,19}$

Kualitas hidup subjek penelitian yang menerima transfusi darah 3 bulan terakhir lebih tinggi $(61,60)$ dibandingkan dengan pasien yang tidak mendapat transfusi darah $(52,40)$. Berdasarkan literatur, pasien yang menerima transfusi darah 3 bulan terakhir memiliki skor total kualitas hidup yang lebih rendah dibandingkan dengan pasien yang tidak mendapat transfusi darah, alasan yang mungkin menjelaskan hal ini adalah dihubungkan dengan kadar $\mathrm{Hb}$ pre-transfusi yang rendah. ${ }^{9}$

Subjek penelitian yang telah menderita talasemia selama $>5$ tahun memiliki kualitas hidup lebih tinggi dibandingkan subjek dengan lama sakit 1-5 tahun atau $<1$ tahun. Hal tersebut berbeda dengan hasil penelitian yang dilakukan oleh Agung $^{16}$ yang melaporkan terdapat hubungan negatif yang bermakna antara lama sakit dengan kualitas hidup.

Hasil penelitian ini didapatkan kualitas hidup anak paling baik pada keluarga dengan penghasilan orangtua $>$ Rp. 3.500.000, kemudian Rp. 2.500.000 Rp. 3.500.000. Semakin tinggi pendapatan orangtua maka kualitas hidup anak semakin baik. ${ }^{9,14,18} \mathrm{Hal}$ tersebut didukung oleh data yang didapatkan dari Pusat Thalassemia Departemen Ilmu Kesehatan Anak FKUI RSCM. Didapatkan bahwa biaya pengobatan anak talasemia selama satu tahun sebesar tiga ratus juta rupiah. Pendapatan orangtua diharapkan dapat mendukung tata laksana pasien (misalnya transportasi ke rumah sakit, biaya kelasi besi, transplantasi sumsum tulang) sehingga dapat meningkatkan kualitas hidup. ${ }^{18}$

\section{Kesimpulan}

Rerata kualitas hidup penderita talasemia di Rumah Sakit Umum Cut Meutia Aceh Utara adalah buruk, khususnya pada fungsi sekolah. Kelompok usia 13-18 tahun memiliki nilai rata-rata kualitas hidup yang lebih tinggi dibandingkan kelompok usia yang lain. Subjek laki-laki mempunyai kualitas hidup yang lebih tinggi dibanding perempuan. Kualitas hidup subjek dengan tingkat pendidikan SMA/sederajat mempunyai nilai yang lebih tinggi dibandingkan tingkat pendidikan yang lain. Kualitas hidup subjek dengan kadar $\mathrm{Hb}$ pretransfusi $<9 \mathrm{~g} / \mathrm{dL}$ didapatkan lebih baik daripada subjek dengan kadar $\mathrm{Hb}$ pre-transfusi $>9 \mathrm{~g} / \mathrm{dL}$. Subjek yang mendapat transfusi 3 bulan terakhir memiliki kualitas hidup yang lebih tinggi. Subjek yang menderita lama sakit talasemia $>5$ tahun menunjukkan nilai kualitas hidup yang lebih tinggi dibandingkan subjek dengan lama sakit 1-5 tahun atau $<1$ tahun. Subjek dari keluarga dengan pendapatan orangtua per bulan 
$>$ Rp.3.500.000 memiliki kualitas hidup yang lebih tinggi dibandingkan kelompok yang lain.

\section{Daftar pustaka}

1. DeBaun MR, Jones, Melissa JF, Vichinsky EP. Thalassemia syndromes. Dalam: Robert M. Kliegman, penyunting. Nelson Textbook of Pediatrics. Edisi ke-20 . Philadelphia: Elsevier; 2016.h.. 2349-52.

2. WHO. Sickle-cell disease and other haemoglobin disorders. [serial online] [cited 2017 May 23rd]; 2011. Didapat dari : http://www.who.int/mediacentrelfactsheets/fs308/en/.

3. Rokom. Thalasemia bukan penyakit menular.. Pusat Komunikasi Publik, Sekretariat Jenderal Kementerian Kesehatan RI; 2012.

4. Primadi O. Skrining penting untuk cegah thalassemia. Biro Komunikasi dan Pelayanan Masyarakat, Kementerian Kesehatan RI; 2017.

5. Wahyuni MS, Ali M, Rosdiana N, Lubis B. Quality of life assessment of children with thalassemia. Paediatrica Indones 2011;51:163-9.

6. Permono B, Ugrasena IDG. Hemoglobin abnormal. Dalam: Buku ajar hematologi-onkologi anak. Jakarta: Badan Penerbit IDAI; 2012.h...78-81.

7. Pranajaya R, Nurchairina. Faktor yang berhubungan dengan kualitas hidup anak thalasemia. Jurnal Keperawatan 2016 ;12:131-40.

8. Ismail A, Campbell MJ, Ibrahim HM, Jones GL. Healthrelated quality of life in Malaysian children with thalassemia. Biomed 2006;4:1-8.

9. Thavorncharoensap M, Torcharus K, Nuchprayoon I, Riewpaiboon A, Indaratna K, Ubol B. Factors affecting health- related quality of life in Thai children with thalassemia. BMC Blood Disorders 2010;10:1. doi: 10.1186/1471-2326-10-1.

10. Varni JW, Sherman SA, Burwinkle TM, Dickinson PE, Doxon P. The PedsQL family impact module: preliminary reliability and validity. Biomed 2004;55:1-6.

11. Gay LR, Diehl PL. Research methods for business and management. New York: MacMillan Publishing Company; 1992.

12. Varni JW, Burwinkle TM, Seid M. The PedsQL as a pediatric patient-reported outcome: reliability and validity of the PedsQL measurement model in 25.000 chidren. Expert Rev Pharmacoecon Outcomes Res 2005;5:705-19.

13. Brown L. The healthy families program health status assesment (PedsQL) final report. Sacramento, CA: Managed Risk Medical Insurance Board; 2004.

14. Mariani D. Analisis faktor yang memengaruhi kualitas hidup anak thalasemia beta mayor di RSU Kota Tasikmalaya dan Ciamis, tesis. Depok: Universitas Indonesia, 2011.

15. Raj M, Sudhakar A, Roy R, Champaneri B Joy TM, Kumar RK. Health-related quality of life in Indian children: a community-based cross-sectional survey. Indian J Med Res 2017;145:521-9.

16. Agung L. Hubungan lama sakit terhadap kualitas hidup anak penderita thalassemia di RSUD dr. Moewardi, skripsi. Surakarta: Universitas Sebelas Maret, 2012.

17. Sultana R, Humayun, Shamsa, Noor, Sara, Zafar U. Impact of thalassaemia on quality of life. SOGP 2016;6:156-60.

18. Aji DN, Silman C, Aryudi C, Centauri C, Andalia D, Astari D, dkk. Faktor-faktor yang berhubungan dengan kualitas hidup pasien thalassemia mayor di Pusat Thalassemia Departemen Ilmu Kesehatan Anak RSCM. Sari Pediatri 2009;11: 85-9.

19. Bulan S. Faktor-faktor yang Berhubungan dengan Kualitas Hidup Anak Thalassemia Beta Mayor, tesis. Semarang: Universitas Diponegoro, 2009. 